Contributions:

A Study design/planning

B Data collection/entry

C Data analysis/statistics

C Data analysis/statistics

D Data interpretation

E Preparation of manuscrip

F Literature analysis/search

$\mathrm{G}$ Funds collection

\title{
CERVICAL AND OCULAR VESTIBULAR EVOKED MYOGENIC POTENTIALS IN MIGRAINE PATIENTS
}

Abeir Osman Dabbous ${ }^{1, A, C-E}$, Nevin Mohieldin Shalaby $2, A-B, D$
Alaa El-Din Ahmed Abousetta

${ }^{1}$ Audio-Vestibular Unit, Department of Otolaryngology, Kasr-Al-Ainy

Faculty of Medicine, Cairo University, Egypt

${ }^{2}$ Neurology Department, Kasr-Al-Ainy Faculty of Medicine, Cairo University, Egypt

${ }^{3}$ Audio-vestibular Unit, Department of Otolaryngology, Suez-Canal University, Egypt

Corresponding author: Abeir Osman Dabbous; Audio-Vestibular Unit, Department of Otolaryngology, Kasr-Al-Ainy Faculty of Medicine, Cairo University, 12211, Cairo, Egypt; email: abeirdabbous@kasralainy.edu.eg

\section{Abstract}

Introduction: In migraine, there is no anatomical correlate of vertigo and no structural abnormality is evident in conventional imaging. Cervical vestibular-evoked myogenic potential (cVEMP) is an uncrossed inhibitory vestibulo-spinal reflex (VSR), while ocular VEMP (oVEMP) represents a crossed excitatory vestibulo-ocular reflex (VOR).

Objective: This study aims at functional evaluation of the findings of cVEMP and oVEMP in migraine patients.

Material and methods: This was a cross-sectional case-control study that included 20 migraine patients as the case group and 30 healthy adult subjects as a control group. All participants were subjected to history taking, otological examination, basic audiological evaluation, bedside examination of the dizzy patient, cVEMP, oVEMP, and posturography tests.

Results: $35 \%$ of migraine patients showed delayed cVEMP latency and $40 \%$ showed abnormal oVEMP in the form of statistically significant delayed right oVEMP P1 $(p=0.050)$ and left oVEMP N1 latency $(p=0.038)$ compared with controls. cVEMP parameters were not correlated to posturography results. The majority of migraine patients $(70 \%)$ had normal equilibrium pattern and normal sensory analyses ratios (65\%). Only $30 \%$ had vestibular dysfunction.

Conclusions: VSR and VOR are affected in migraine patients. We recommend the use of cVEMP and oVEMP in migraine patients for functional assessment of brainstem pathways.

Key words: vertigo $\bullet$ vestibulo-ocular reflex $\bullet$ vestibulo-spinal reflex

\section{SZYJNE I OCZNE MIOGENNE PRZEDSIONKOWE POTENCJAŁY WYWOŁANE U PACJENTÓW Z MIGRENĄ}

\section{Streszczenie}

Wprowadzenie: W migrenie nie wystepują anatomiczne korelaty zawrotów głowy, a w konwencionalnych badaniach obrazowych nie uwidaczniają się nieprawidłowości strukturalne. Szyjny miogenny przedsionkowy potencjał wywołany (cVEMP) jest hamującym odruchem przedsionkowordzeniowym (VSR), realizowanym przez włókna nerwowe nieskrzyżowane, podczas gdy oczny miogenny przedsionkowy potencjał wywołany (oVEMP) reprezentuje pobudzający odruch przedsionkowo-oczny (VOR), realizowany przez włókna nerwowe skrzyżowane.

Cel: Celem badania jest funkcjonalna ocena wyników badań cVEMP i oVEMP u pacjentów z migreną.

Materiał i metody: Przeprowadzono badanie przekrojowe z grupą kontrolną. W grupie badanej znalazło się 20 pacjentów z migreną, a w grupie kontrolnej - 30 zdrowych dorosłych osób. Wszyscy uczestnicy przeszli następujące procedury: wywiad medyczny, badania otologiczne i audiologiczne, badanie zawrotów głowy w pozycji leżącej, badania cVEMP i oVEMP, a także posturografię.

Wyniki: U 35\% pacjentów z migreną, w porównaniu do grupy kontrolnej, stwierdzono wydłużoną latencję cVEMP, a 40\% miało nieprawidłowe oVEMP w postaci statystycznie istotnego opóźnienia latencji P1 oVEMP po stronie prawej $(p=0,050)$ i latencji N1 oVEMP po stronie lewej $(p=0,038)$. Parametry cVEMP nie były skorelowane $\mathrm{z}$ wynikami badania posturograficznego. U większości pacjentów migrenowych (70\%) stwierdzono normalne wzorce równowagi i normalne wyniki analizy sensorycznej (65\%). Tylko u 30\% badanych występowały zaburzenia przedsionkowe.

Wnioski: Pacjenci z migreną mają zaburzone odruchy VSR i VOR. Zalecamy wykonywanie u pacjentów migrenowych badań cVEMP i oVEMP w celu oceny funkcjonowania ścieżek pnia mózgu.

Słowa kluczowe: zawroty głowy • odruch przedsionkowo-oczny • odruch przedsionkowo-rdzeniowy

\section{Introduction}

Migraine is a common disabling primary headache disorder. There are two major types: 1) Migraine without aura is a clinical syndrome characterized by headache with specific features and associated symptoms; 2) Migraine with aura is primarily characterized by transient focal neurological symptoms that usually precede or sometimes accompany the headache. Some patients also experience a prodromal phase, occurring hours or days before 
the headache, and/or a postdromal phase following headache resolution. Prodromal and postdromal symptoms include hyperactivity, hypoactivity, depression, cravings for particular foods, repetitive yawning, fatigue, and neck stiffness and/or pain for years [1].

Vestibular migraine (VM) is one of the most common neurological disorders causing vertigo and dizziness (it was previously termed migraine-associated vertigo/dizziness; migraine-related vestibulopathy; or migrainous vertigo) [2]. There are five major diagnostic criteria for VM, labelled A to E as follows. A) At least five episodes fulfilling criteria C and D. B) A current or past history of Migraine without aura or Migraine with aura. C) Vestibular symptoms of moderate or severe intensity, lasting between $5 \mathrm{~min}$ and $72 \mathrm{~h}$. D) At least half the episodes are associated with at least one of the following three migrainous features: 1 . headache with at least two of the following four characteristics: a) unilateral location, b) pulsating quality, c) moderate or severe intensity, d) aggravation by routine physical activity, 2. photophobia and phonophobia, 3. visual aura. E) Not better accounted for by another ICHD-3 diagnosis or by another vestibular disorder [1].

Although vertigo is reported by more than $60 \%$ of patients with Migraine with brainstem aura, the International Classification of Headache Disorders, 3rd edition (ICHD-3) requires at least two brainstem symptoms in addition to visual, sensory, or dysphasic aura symptoms for this diagnosis. Fewer than $10 \%$ of patients with Vestibular migraine fulfill these criteria. Therefore, Vestibular migraine and Migraine with brainstem aura are not synonymous, although individual patients may meet the diagnostic criteria for both disorders [1].

The cervical vestibular-evoked myogenic potential (cVEMP) assesses the descending vestibular pathway via the uncrossed ipsilateral sacculo-collic reflex, while the ocular VEMP (o-VEMP) test has been validated for evaluation of the ascending vestibular pathway via the crossed utriculo-ocular reflex [3]. Central vestibular lesions may impair VEMP responses along the descending and ascending tracts in the brainstem [4-7]. Computerized dynamic posturography (CDP) is a test of a person's ability to maintain balance by effectively using visual, vestibular, and somatosensory inputs separately as well as suppressing or compensating for inaccurate or challenging sensory information. CDP can complement the results of conventional vestibular tests in specific situations, such as analyses of the vestibulo-spinal reflex (VSR) and sensory analyses of balance disorders [8].

In migraine, no structural abnormality shows on conventional imaging; that is, there is no anatomical correlate of vertigo. There is then a need to assess functional abnormality in migraineurs using electrophysiological testing. This study aims to evaluate of the findings of cervical and ocular vestibular evoked myogenic potentials (cVEMP and oVEMP) in migraine patients and to relate VEMP parameters to the clinical presentation and other vestibular tests.

\section{Material and methods}

The study group included 20 adult migraineurs having dizziness with or without vertigo. Migraine with and without aura was diagnosed according to the diagnostic criteria of the International Classification of Headache Disorders (ICHD-3) [1,9]. All complained of dizziness, while $12(60 \%)$ had vertigo, and all fitted the new diagnostic criteria of "vestibular migraine" according to the ICHD-3 [1].

The study group was compared to 30 healthy adult volunteer subjects as the control group. The study was approved by the Research Ethical Committee and Otolaryngology department council of the Faculty of Medicine, Cairo University. Informed consent was signed by all participants. Tests were performed in the Audiology Unit outpatient clinic during the period March 2016 to March 2020. Exclusion criteria were peripheral vestibular disorder, postural hypotension, general diseases causing peripheral neuropathy, patients with neurological disorders, or with peripheral extra-ocular muscle paresis or visual Scores defects hindering the testing. Patients were tested during the interictal period. Participants were subjected to the following 9 tests.

1) History taking and assessment of the severity of dizziness/vertigo using the Arabic translation [10] of the Dizziness Handicap Inventory (DHI) [11]. The DHI is a 25-item self-assessment inventory that pertains to dizziness or unsteadiness problems. Questions are designed to address the impacts of balance system disease on a person's functional (F) aspects (i.e., on their everyday life), emotional (E) impacts (the effects on their emotional well-being), and physical (P) impacts (the effects on their stability). The DHI is therefore made up of an E-subscale score, an F-subscale score, and a P-subscale score as well as a total score. Each subscale was analyzed separately and by scoring the handicap according to the total score. A total score of zero reflects no handicap, while the maximum is 100 . A total score of 16-34 points reflects mild handicap, $36-52$ points moderate handicap, and $\geq 54$ points severe handicap. 2) General and neurological examination. 3) ENT examination. 4) Basic audiological assessment, including pure tone audiometry, speech audiometry, tympanometry, and acoustic reflex threshold measurement. 5) Bedside examination of the dizzy patient. 6) Video-nystagmography (Micromedical Corp, USA), including oculomotor and positional, as well as caloric testing. 7) Subjective visual vertical (SVV) test (Difra, Belgium). 8) VEMP tests (Neuro-Audio, Neurosoft Ltd, Russia). For cVEMP, the active electrode was placed on the middle of the sterno-cleido-mastoid (SCM) muscle; the reference electrode on the upper sternum (suprasternal notch), and the ground electrode on the forehead. Electrode impedance was kept below $5 \mathrm{k} \Omega$. Subjects were instructed to sit upright and tense the muscle by turning their chin to the contralateral shoulder. Rectified EMG was monitored during recordings to ensure low noise. Stimuli were tone bursts of $500 \mathrm{~Hz}$ with rise and fall times of $1 \mathrm{~ms}$ and plateau of $2 \mathrm{~ms}$ presented monoaurally at $5 \mathrm{~Hz}$ through insert phones at $100 \mathrm{dBnHL}$. At least 60 sweeps were obtained using a $30-2000 \mathrm{~Hz}$ filter. The time window for analysis was $50 \mathrm{~ms}$. For oVEMP, the positive electrode was placed on the orbital margin below the center of the eye and the reference electrode placed $15-30 \mathrm{~mm}$ below the positive electrode, on the cheek, with the ground electrode on the forehead. Subjects were instructed to sit upright, relax their facial muscles, and look up with their eyes without moving their head. At least 200 sweeps were made with a $1-1000 \mathrm{~Hz}$ filter. Other conditions were the 
same as with cVEMP. VEMP responses were judged as either present or absent according to the presence or absence of a biphasic response. Parameters measured were latency in $\mathrm{ms}$ and amplitude in $\mu \mathrm{V}$. For cVEMP, measurements were made of $\mathrm{P} 13$ latency, N23 latency, P13-N23 peak-topeak amplitude, and the inter-aural amplitude difference (IAAD) ratio or the amplitude asymmetry ratio, which is the peak to peak amplitude difference between the 2 ears divided by the total amplitude of both ears. For oVEMP, measures were N10 latency, P15 latency, N10-P15 peakto-peak amplitude, and IAAD. 9) A sensory organization test (SOT) using computerized dynamic posturography (CDP). An equilibrium score (EQ) was calculated for each of the 6 SOT conditions, and a composite EQ was calculated. Ratios were used to identify possible impairments of an individual's sensory system. a) The somato-sensory (SOM) ratio (condition $2 /$ condition 1 ); b) the visual (VIS) ratio (condition 4/condition 1); c) the vestibular (VEST) ratio (condition 5/condition 1 ), which assesses the ability to use input from each sensory system to control balance; and d) the vision preference (PREF) ratio [(condition $3+6) /($ condition $2+5)$ ], which assess the extent to which a subject relies on visual input to control balance, even when the visual information is incorrect.

Statistical analysis methods. Data collected was coded using Microsoft Excel 2010, and then imported into SPSS (Statistical Package for Social Science) version 19.0 for analysis. According to the type of data, the following tests were performed to test differences for significance: Mann-Whitney $U$-test (if the data were not normally distributed) and Chisquare test with least significant difference. Pearson's correlation test was used to determine correlations between individual results. Differences were considered statistically significant at $p<0.05$.

\section{Results}

Cases comprised 16 (80\%) females, and 4 (20\%) males, with a mean age of $35.1 \pm 6.7$ (range 22 to 44 years). Controls comprised 17 (57\%) females and 13 (43\%) males, with a mean age of $32.8 \pm 5.4$ (range 24 to 44 years). Groups were matched in terms of age and gender. The mean migraine duration was $6.0 \pm 3.7$ years (range 1-15) and mean migraine attacks/month was $3.2 \pm 1.4$ (range 0-6). The mean migraine attack duration was $3.3 \pm 1 \mathrm{~h}$ (range $2-5)$. There were $14 / 20$ (70\%) of migraine patients who were under treatment. Twelve patients $(60 \%)$ had phonophobia; 13 (65\%) had photophobia, 3 (15\%) had allodynia, $14(70 \%)$ had nausea, $6(30 \%)$ had vomiting, $16(80 \%)$ had aura - visual in $12(60 \%)$, sensory in $9(45 \%)$, and motor in $3(15 \%)$, diplopia in $4(20 \%)$, blurring in $9(45 \%)$, and tinnitus in $4(20 \%)$. All migraineurs complained of dizziness, while 12 (60\%) had vertigo.

Regarding the DHI, the mean F-score was $17.5 \pm 2.7$ (range 12-22), the mean $P$-score was $6.7 \pm 2.18$ (range $4-10$ ), the mean $E$-score was $15.4 \pm 1.96$ (range 12 to 18 ), and the mean total score was $39.6 \pm 5.72$ (range $28-50$ ). There were $5 / 20(25 \%)$ who had mild handicap, while 15/20 (75\%) had moderate handicap. Regarding PTA: 19 (95\%) and 18 (90\%) of migraine patients had normal hearing, while $1(5 \%)$ and $2(10 \%)$ had high frequency hearing loss (at $8 \mathrm{kHz}$ ) in the right and left ears respectively.
There were statistically significant differences between the migraine group and the control group regarding EQ scores (under conditions $\mathrm{C} 1, \mathrm{C} 2$, and $\mathrm{C} 6$ ) and in the SOM ratio (Table 1). Table 2 shows EQ deficits and affected sensory analyses. Normal EQ was found in 13/20 (65\%) and normal SA ratios in 14/20 (70\%).

None of the migraine patients had any oculographic abnormality. There were no statistically significant differences between migraine patients and normal controls regarding the SVV test. cVEMP and oVEMP were present bilaterally in all subjects. There were no statistically significant differences between migraine patients and controls regarding cVEMP, except for a statistically significant smaller IAAD\%, but it was still within the normal range (Table 3). For oVEMPs, there were statistically significant delayed Rt oVEMP P1 and Lt oVEMP N1 latency in the migraineurs compared to their controls; there was also statistically significant smaller Rt oVEMP rectified amplitude in the migraine patients compared to their controls (Table 4). Figure 1 shows cVEMP and oVEMP traces in one of our normal controls, and for comparison, Figure 2 shows cVEMP and oVEMP traces in one of our migraine patients.

According to our normative values for cVEMP, IAAD $\%>36.55 \%$ was considered abnormal, reflecting amplitude asymmetry; similarly, P13 > $16.73 \mathrm{~ms}(\mathrm{Rt})$, $15.97 \mathrm{~ms}$ (Lt), N23 > $26.68 \mathrm{~ms}$ (Rt), and $25.74 \mathrm{~ms}(\mathrm{Lt})$ were considered abnormal. For oVEMP, IAAD\% $>36.10 \%$, $\mathrm{N} 1>11.95 \mathrm{~ms}$ (Rt), $12.12 \mathrm{~ms}$ (Lt), P1 > $17.29 \mathrm{~ms}$ (Rt), $19.50 \mathrm{~ms}(\mathrm{Lt})$ were considered abnormal. The final VEMP result was considered normal if both the latency and amplitude were normal and were considered abnormal if either or both were abnormal. Table 5 shows, for migraineurs, the distribution of latency and amplitude asymmetry abnormalities, and the final cVEMP and oVEMP results. There was no statistically significant difference regarding the relation between the distribution of cVEMP and oVEMP abnormality results.

There were no statistically significant differences between cVEMP and oVEMP findings in migraineurs when compared with those with/without nausea, vomiting, allodynia, phonophobia, or vertigo. Although migraine patients with phonophobia had larger cVEMP amplitude than those without phonophobia, all migraineurs with and without phonophobia had symmetrical IAAD.

Statistically, there was significantly more IAAD oVEMP symmetry in those with photophobia compared to those without photophobia. All migraineurs with photophobia had symmetrical IAAD while $71.4 \%$ of those without photophobia had asymmetrical IAAD and this distribution was statistically significant. There was a statistically significant larger Rt and Lt cVEMP P13-N23 amplitude and Rt and Lt cVEMP rectified amplitude in those with aura compared to those without aura.

All migraineurs with vertigo had symmetrical oVEMP amplitude compared to $75 \%$ of those without vertigo, and this distribution was not statistically significant. In migraineurs there was no statistically significant difference in the distribution of cVEMP and oVEMP abnormality in terms of the presence or absence of vertigo. Similarly, 
Table 1. Comparison between migraine patients and their controls according to equilibrium scores in the 6 SOT conditions (C1-C6), composite scores, and sensory analysis ratios

\begin{tabular}{|c|c|c|c|c|c|c|c|c|c|c|}
\hline \multirow[b]{2}{*}{$\begin{array}{l}\text { Equilibrium } \\
\text { scores }\end{array}$} & \multirow[b]{2}{*}{ Mean } & \multicolumn{3}{|c|}{ Controls $(n=30)$} & \multicolumn{4}{|c|}{ Migraine $(n=20)$} & \multirow{2}{*}{$Z * *$} & \multirow{2}{*}{$p$} \\
\hline & & SD & Min & Max & Mean & SD & Min & Max & & \\
\hline C1 & 95.24 & 2.4 & 90.3 & 98.6 & 93.05 & 4 & 79.33 & 97.5 & -2.162 & $0.031 *$ \\
\hline $\mathrm{C} 2$ & 92.76 & 3.26 & 82.3 & 97.6 & 89.05 & 5.47 & 73 & 96 & -2.834 & $0.005^{*}$ \\
\hline C3 & 90.21 & 4.47 & 81.3 & 98.6 & 87.8 & 5.48 & 78.33 & 95.6 & -1.605 & 0.109 \\
\hline C4 & 85.69 & 5.26 & 77.3 & 98.4 & 82.17 & 8.15 & 54.3 & 89.6 & -1.347 & 0.178 \\
\hline C5 & 70.41 & 7.38 & 57.6 & 92.4 & 64.65 & 14.94 & 38 & 90 & -1.406 & 0.16 \\
\hline C6 & 69.71 & 8.79 & 55.3 & 90.1 & 58.12 & 18.71 & 17.33 & 94 & -2.506 & $0.012^{*}$ \\
\hline Composite score & 79.17 & 5.82 & 71 & 92 & 75.15 & 8.44 & 58 & 91 & -1.836 & 0.066 \\
\hline SOM ratio & 97.35 & 3.03 & 84.67 & 100 & 94.84 & 5.02 & 78.07 & 100 & -2.125 & $0.034^{*}$ \\
\hline VIS ratio & 89.68 & 5.34 & 80.3 & 100 & 88.4 & 8.73 & 56.56 & 96.17 & -0.089 & 0.929 \\
\hline VEST ratio & 73.6 & 7.51 & 60.4 & 97.8 & 68.7 & 15.37 & 40.42 & 94.24 & -1.129 & 0.259 \\
\hline PREF ratio & 96.48 & 4.46 & 83.2 & 100 & 91.97 & 8.87 & 65.16 & 100 & -1.869 & 0.062 \\
\hline
\end{tabular}

$Z^{* *}$ of Mann-Whitney test

${ }^{*} \mathrm{p}$-value is statistically significant

there were no statistically significant differences between migraineurs with and without vertigo regarding posturography. There were no statistically significant differences between migraineurs with and without normal composite score or VEST ratio score regarding cVEMP findings.

As the age of migraineurs patients increased, the rectified Lt oVEMP decreased (a weak negative correlation) (Table 6). As F-score of the DHI increased, the cVEMP N23 latency on the Rt side was delayed (weak positive correlation). As $P$-score of the DHI increased, the Rt P13-N23 amplitude cVEMP decreased (fair negative correlation). As $P$-score of the DHI increased, the Rt and Lt rectified cVEMP amplitude decreased (fair negative correlations). As the total and the E-score of the DHI increased, the Rt P13-N23 rectified cVEMP amplitude decreased (fair negative correlation) (Table 7).

\section{Discussion}

In the current study, there was no statistically significant difference in cVEMP latency between migraineurs and controls. Although there was a statistically significant smaller IAAD\% than the controls, it was within normal limits and so all cases had symmetrical cVEMP. The amplitude results agree with Shalaby et al. [12], Kim et al. [13], and Khalil et al. [14]. However, Kang et al. [15] found a prolonged latency in the cVEMP test in VM patients. In terms of amplitudes, Kang et al. [15], Baier et al. [16], and Salviza et al. [17] all reported bilaterally reduced cVEMP amplitudes in VM patients compared to controls. Makowiec et al. [18] found that in patients with VM the most common cVEMP abnormality was either asymmetrical amplitude or complete absence of VEMP.

In our study, migraineurs showed statistically significant delayed oVEMP latencies compared to controls. This reflects vestibulo-ocular reflex (VOR) pathology, which agrees with Kim et al. [13]. Our result of oVEMP amplitude asymmetry, accords with Inoue et al. [18], Makowiec et al. [19], and Zaleski et al. [20]. Significant oVEMP N1P1 amplitude differences have been found between healthy and migraine groups [19], but in other studies the difference did not reach statistical significance $[13,14]$.

In the current study, even though the mean cVEMP latency of the whole group was comparable to the controls, 7 migraine cases (35\%) had abnormal cVEMP due to delayed latency, indicating that the vestibulo-spinal reflex (VSR) was affected. oVEMP abnormality in the form of latency delay was found in $8 / 20$ patients $(40 \%)$, including 2 that also had amplitude asymmetry (IAAD\%).

In comparison, Jung et al. [21] found abnormal cVEMP measurements in $29 \%$ of VM patients. Inoue et al. [18] did not find any significant difference between VM patients and controls in terms of the prevalence of abnormal airconducted cVEMPs or oVEMPs: $39 \%$ cVEMPs abnormality in VM versus $22 \%$ for controls, and 35\% oVEMPs abnormality in VM versus $8 \%$ for controls. At the same time, Inoue and colleagues found no significant differences in response amplitude or latencies for cVEMPs or oVEMPs between VM patients and controls [18]. Khalil et al. [14] found that 5 of $20 \mathrm{VM}$ patients (25\%) had normal cVEMP responses and 15 (75\%) had abnormal cVEMPs, while the majority (95\%) of VM patients (19/20) had abnormal oVEMP responses.

In the current study, only $3 / 20(15 \%)$ of migraine patients showed abnormality in both cVEMP and oVEMP, while $8 / 20$ (40\%) showed normal results in both, 5/20 (25\%) showed normal cVEMP but abnormal oVEMP, and 4/20 (20\%) showed normal oVEMP but abnormal cVEMP. However, this abnormality distribution was not significant. 
Table 2. Equilibrium deficit findings, affected sensory analyses ratios, and abnormalities in the migraine patients

\begin{tabular}{|c|c|c|}
\hline & & \\
\hline & & \\
\hline Equilibrium deficit & No. & $\%$ \\
\hline Normal (no deficits) & 13 & 65 \\
\hline Visual preference/vestibular dysfunction pattern & 1 & 5 \\
\hline Visual/vestibular dysfunction pattern & 1 & 5 \\
\hline Severe dysfunction pattern & 0 & 0 \\
\hline Vestibular dysfunction pattern & 4 & 20 \\
\hline Visual preference pattern & 1 & 5 \\
\hline Sensory analyses (affected sensory ratios) & No. & $\%$ \\
\hline Normal SA ratios & 14 & 70 \\
\hline Abnormalities & No. & $\%$ \\
\hline VEST & 4 & 20 \\
\hline VIS & 0 & 0 \\
\hline PREF & 0 & 0 \\
\hline VEST / SOM & 1 & 5 \\
\hline VEST / VIS & 1 & 5 \\
\hline Abnormalities & No. & $\%$ \\
\hline SOM ratio & 1 & 5 \\
\hline VIS ratio & 1 & 5 \\
\hline VEST ratio & 6 & 30 \\
\hline PREF ratio & 0 & 0 \\
\hline
\end{tabular}

Numbers are not mutually exclusive as a patient can have multiple abnormalities (i.e., numbers do not add up to the total numbers in each group)

Table 3. Comparison of cVEMP parameters between migraine patients $(n=20)$ and normal controls $(n=30)$

\begin{tabular}{|c|c|c|c|c|c|c|c|c|c|c|}
\hline & \multirow{3}{*}{ cVEMP } & \multicolumn{4}{|c|}{ Migraine patients } & \multicolumn{4}{|c|}{ Controls } & \multirow{3}{*}{$p$-value } \\
\hline & & \multicolumn{4}{|c|}{$(n=20)$} & \multicolumn{4}{|c|}{$(n=30)$} & \\
\hline & & mean & SD & $\min$ & $\max$ & mean & SD & $\min$ & $\max$ & \\
\hline \multirow{4}{*}{ Rt } & P13 (in ms) & 15.32 & 2.81 & 11.4 & 21.8 & 14.22 & 1.25 & 12 & 16.5 & 0.067 \\
\hline & N23 (in ms) & 22.22 & 2.55 & 18.4 & 26.5 & 22.18 & 2.25 & 16.5 & 27.5 & 0.957 \\
\hline & P13-N23 amplitude in $\mu \mathrm{V}$ & 46.55 & 17.36 & 19 & 91 & 44.41 & 19.36 & 10.7 & 89.7 & 0.691 \\
\hline & $\begin{array}{c}\text { rectified P13-N23 amplitude } \\
\text { in } \mu \mathrm{V}\end{array}$ & 0.89 & 0.43 & 0.3 & 1.9 & 1.05 & 0.57 & 0.2 & 2.7 & 0.282 \\
\hline \multirow{4}{*}{ Lt } & P13 (in ms) & 14.96 & 2.42 & 11 & 19.6 & 14.07 & 0.95 & 12.3 & 16.1 & 0.077 \\
\hline & N23 (in ms) & 21.73 & 2.71 & 17.5 & 26.5 & 21.92 & 1.91 & 17.3 & 26.2 & 0.763 \\
\hline & P13-N23 amplitude in $\mu \mathrm{V}$ & 53.62 & 25.79 & 22.1 & 111.1 & 43.97 & 22.03 & 8.1 & 92.1 & 0.163 \\
\hline & $\begin{array}{c}\text { Rectified P13-N23 amplitude } \\
\text { in } \mu \mathrm{V}\end{array}$ & 1.07 & 0.58 & 0.4 & 2.3 & 1.09 & 0.64 & 0.2 & 3.2 & 0.888 \\
\hline IAAD\% & & 9.39 & 6.51 & 0.2 & 22.8 & 16.53 & 10.01 & 0.2 & 30.4 & $0.007^{*}$ \\
\hline \multicolumn{2}{|c|}{ Rectified IAAD\% } & 15.42 & 12.44 & 0 & 41 & 16.22 & 10.52 & 0 & 35 & 0.806 \\
\hline
\end{tabular}

* $p$-value is statistically significant 
Table 4. Comparison of oVEMP parameters between migraine patients $(n=20)$ and normal controls $(n=30)$

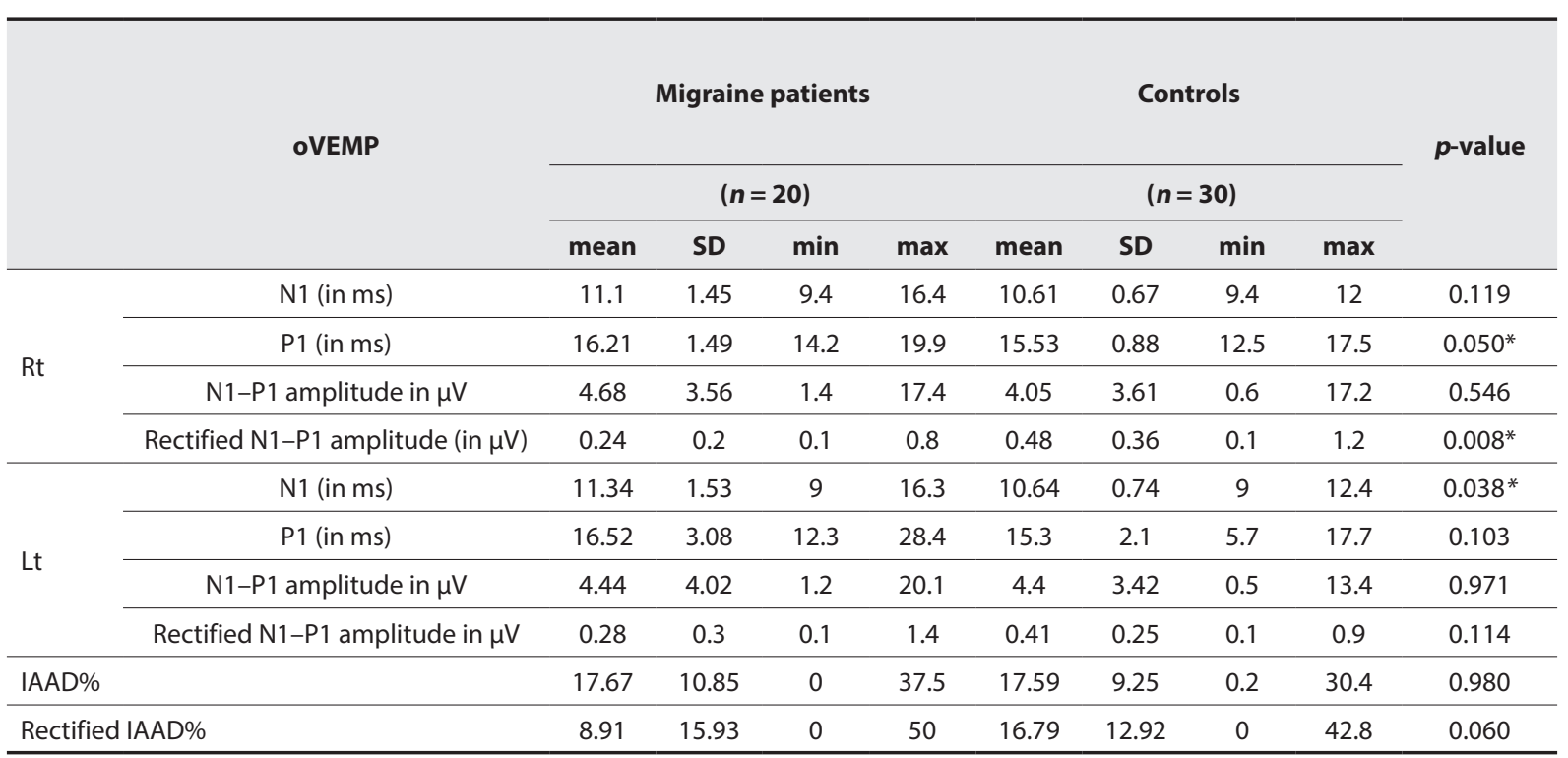

${ }^{*} p$-value is statistically significant

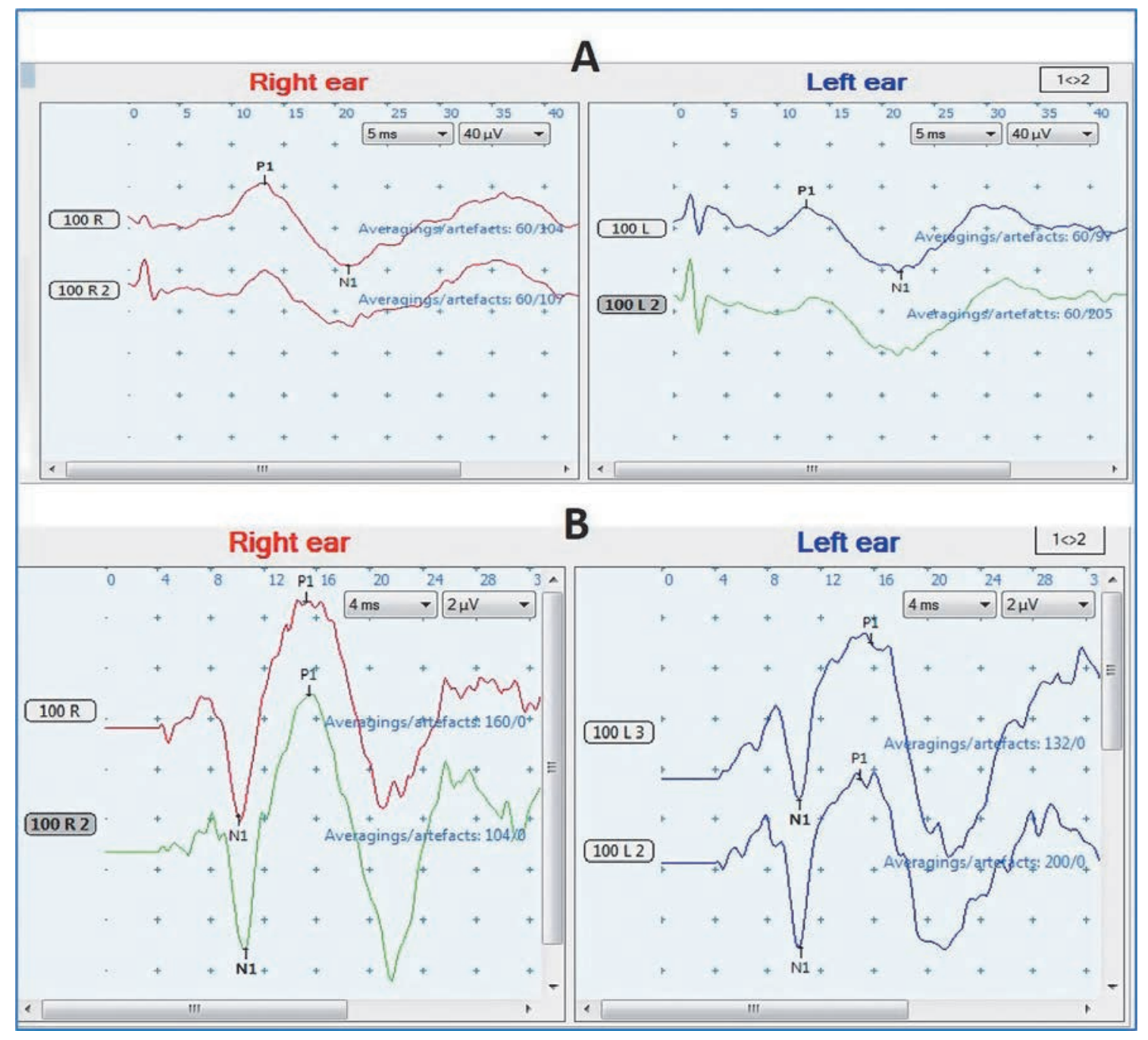

Figure 1. Example traces of $\operatorname{cVEMP}(A)$ and oVEMP (B) in one of our normal controls (female, 36 years old) 


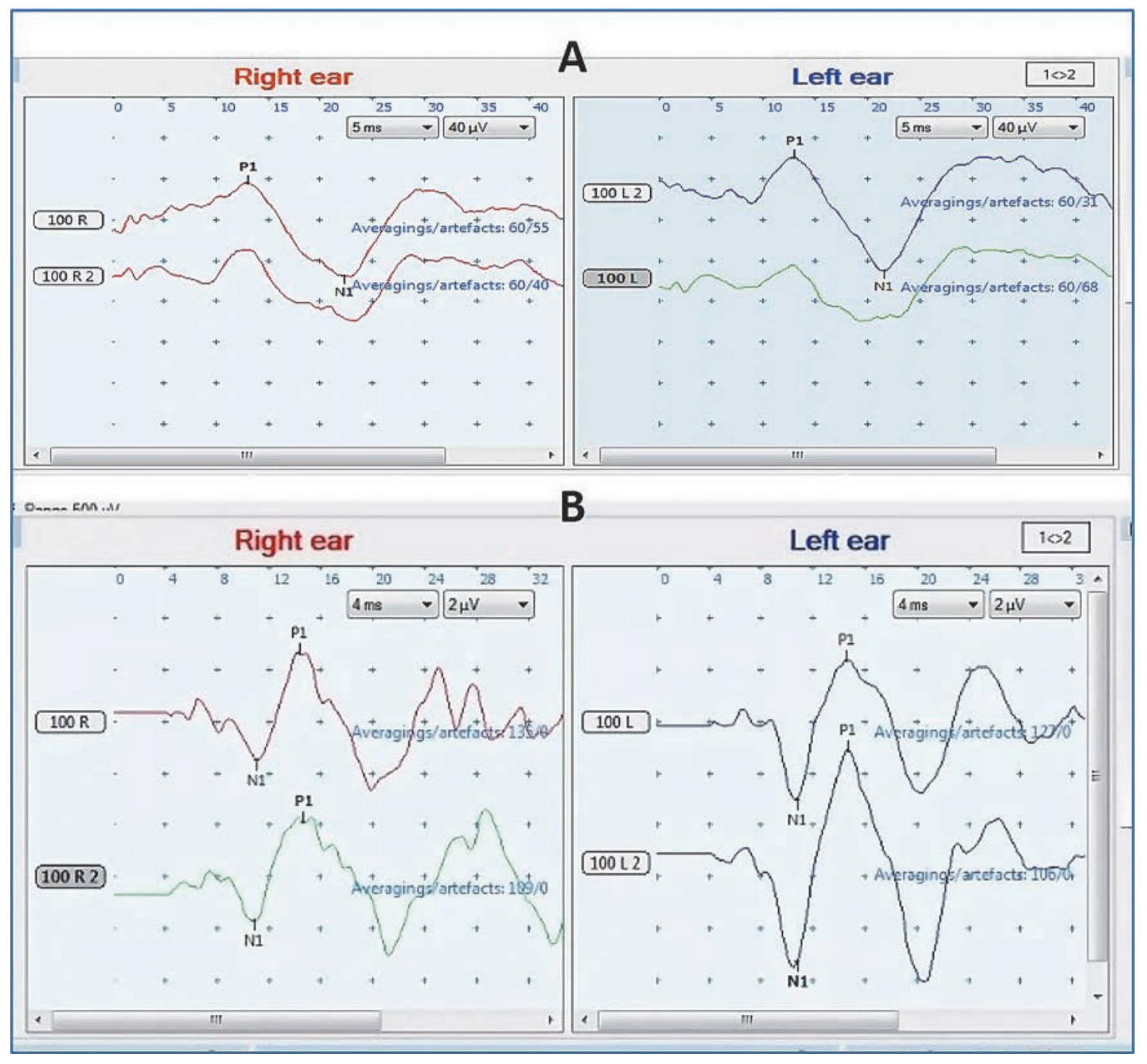

Figure 2. Example traces of $\operatorname{cVEMP~}(\mathrm{A})$ and $\operatorname{oVEMP}(\mathrm{B})$ in one of our migraine patients (female, 38 years old)

Table 5. Relation between of cVEMP and oVEMP results (including latency, asymmetry, or loss) in migraine patients. There was no statistically significant difference regarding the relation between the distribution cVEMP and oVEMP abnormality results

\begin{tabular}{lcccc}
\hline & \multirow{2}{*}{ Migraine } & \multicolumn{2}{c}{ cVEMP result } & \multirow{2}{*}{ Total } \\
\cline { 3 - 4 } & & Abnormal & Normal & \\
\hline \multirow{2}{*}{ oVEMP result } & Abnormal & $3(15 \%)$ & $5(25 \%)$ & $\neq 8(40 \%)$ \\
\cline { 2 - 4 } & Normal & $4(20 \%)$ & $8(40 \%)$ & $12(60 \%)$ \\
\hline Total & & $\dagger 7(35 \%)$ & $13(65 \%)$ & $20(100 \%)$ \\
\hline$X^{2}=0.037, p=1.000$ & & & &
\end{tabular}

†All migraine cases with abnormal cVEMP $(n=7)$ had delayed latency, even though they all had symmetrical amplitude. All cVEMP abnormalities in migraine patients were in the form of latency delay. ¥Migraine cases with abnormal oVEMP $(n=8)$ had delayed latency including 2 with amplitude asymmetry

In comparison, Makowiec et al. [19] concluded that patients with VM are more likely than subjects with vestibular disorders other than migraine to exhibit normal cVEMP responses in the presence of unilaterally abnormal oVEMP responses. Such a VEMP pattern may be a biomarker of VM and further supports a possible pathophysiologic relationship between the utriculo-ocular reflex and VM.
Our cVEMP and oVEMP findings were not correlated to any clinical symptom, except that cVEMP amplitude was statistically significant larger in both ears of migraine patients with aura compared to those without aura. However, Sürmeli et al. [22] found that the cVEMP P13N23 amplitudes in migraine patients with aura were significantly smaller than in patients without aura. In their 
Table 6. Correlation between CVEMP and oVEMP findings and age of migraine patients $(n=20)$

\begin{tabular}{|c|c|c|c|c|c|c|c|c|c|c|c|}
\hline & \multicolumn{11}{|c|}{ cVEMP } \\
\hline & \multicolumn{5}{|c|}{ Rt } & \multicolumn{4}{|c|}{ Lt } & \multirow[b]{2}{*}{ Asymmetry } & \multirow{2}{*}{$\begin{array}{l}\text { Rectified } \\
\text { IAAD\% }\end{array}$} \\
\hline & & P13 & N23 & $\begin{array}{c}\text { P13-N23 } \\
\text { amplitude }\end{array}$ & Rectified & P13 & N23 & $\begin{array}{l}\text { P13-N23 } \\
\text { amplitude }\end{array}$ & Rectified & & \\
\hline \multirow{5}{*}{$\begin{array}{l}\text { Age of } \\
\text { migraine } \\
\text { patients }\end{array}$} & $r$ & -0.106 & 0.102 & -0.245 & -0.318 & -0.053 & 0.078 & -0.212 & -0.16 & 0.378 & 0.138 \\
\hline & $p$ & 0.658 & 0.67 & 0.298 & 0.172 & 0.826 & 0.745 & 0.37 & 0.5 & 0.875 & 0.563 \\
\hline & \multicolumn{11}{|c|}{ oVEMP } \\
\hline & \multicolumn{5}{|c|}{$\mathbf{R t}$} & \multicolumn{4}{|c|}{ Lt } & \multirow[t]{2}{*}{ Asymmetry } & \multirow{2}{*}{$\begin{array}{l}\text { Rectified } \\
\text { IAAD\% }\end{array}$} \\
\hline & & N1 & P1 & $\begin{array}{c}\text { N1-P1 } \\
\text { amplitude }\end{array}$ & Rectified & N1 & P1 & $\begin{array}{c}\text { N1-P1 } \\
\text { amplitude }\end{array}$ & Rectified & & \\
\hline \multirow{2}{*}{$\begin{array}{l}\text { Age of } \\
\text { migraine } \\
\text { patients }\end{array}$} & $r$ & 0.051 & 0.055 & 0.347 & -0.388 & 0.020 & -0.127 & 0.244 & -0.454 & -0.251 & -0.049 \\
\hline & $p$ & 0.831 & 0.819 & 0.134 & 0.091 & 0.932 & 0.594 & 0.300 & $0.044^{*}$ & 0.286 & 0.836 \\
\hline
\end{tabular}

${ }^{*} p$-value is statistically significant

Table 7. Correlation between CVEMP and oVEMP findings and Dizziness Handicap Inventory in migraine patients $(n=20)$

\begin{tabular}{|c|c|c|c|c|c|c|c|c|c|c|c|}
\hline \multirow{3}{*}{$\begin{array}{l}\text { Dizziness } \\
\text { Handicap } \\
\text { Inventory }\end{array}$} & \multicolumn{11}{|c|}{ cVEMP } \\
\hline & \multicolumn{5}{|c|}{$\mathbf{R t}$} & \multicolumn{4}{|c|}{ Lt } & \multirow[b]{2}{*}{ asymmetry } & \multirow{2}{*}{$\begin{array}{l}\text { rectifiec } \\
\text { IAAD\% }\end{array}$} \\
\hline & & P13 & N23 & $\begin{array}{c}\text { P13-N23 } \\
\text { amplitude }\end{array}$ & $\begin{array}{l}\text { rectified } \\
\text { amplitude }\end{array}$ & P13 & N23 & $\begin{array}{l}\text { P13-N23 } \\
\text { amplitude }\end{array}$ & $\begin{array}{l}\text { rectified } \\
\text { amplitude }\end{array}$ & & \\
\hline \multirow{2}{*}{ F-score } & $r$ & 0.268 & 0.462 & -0.22 & -0.189 & 0.083 & 0.312 & -0.151 & -0.067 & 0.091 & 0.037 \\
\hline & $p$ & 0.253 & $0.040^{*}$ & 0.352 & 0.426 & 0.729 & 0.181 & 0.526 & 0.78 & 0.703 & 0.878 \\
\hline \multirow{2}{*}{ P-score } & $r$ & 0.005 & 0.297 & -0.599 & -0.645 & -0.048 & 0.207 & -0.505 & -0.416 & -0.276 & 0.137 \\
\hline & $p$ & 0.983 & 0.204 & $0.005^{*}$ & $0.002^{*}$ & 0.842 & 0.381 & $0.023^{*}$ & 0.068 & 0.239 & 0.565 \\
\hline \multirow{2}{*}{ E-score } & $r$ & 0.138 & 0.131 & -0.289 & -0.521 & 0.121 & 0.197 & -0.337 & -0.356 & -0.397 & 0.074 \\
\hline & $p$ & 0.562 & 0.581 & 0.217 & $0.018^{*}$ & 0.612 & 0.405 & 0.147 & 0.124 & 0.083 & 0.755 \\
\hline \multirow{2}{*}{ total score } & $r$ & 0.174 & 0.373 & -0.43 & -0.512 & 0.062 & 0.292 & -0.378 & -0.311 & -0.198 & 0.095 \\
\hline & $p$ & 0.462 & 0.105 & 0.059 & $0.021^{*}$ & 0.796 & 0.212 & 0.100 & 0.181 & 0.402 & 0.691 \\
\hline \multirow{3}{*}{$\begin{array}{l}\text { Dizziness } \\
\text { Handicap } \\
\text { Inventory }\end{array}$} & \multicolumn{11}{|c|}{ oVEMP } \\
\hline & \multicolumn{5}{|c|}{$\mathbf{R t}$} & \multicolumn{4}{|c|}{ Lt } & \multirow[b]{2}{*}{ asymmetry } & \multirow[b]{2}{*}{$\begin{array}{l}\text { rectified } \\
\text { IAAD\% }\end{array}$} \\
\hline & & N1 & P1 & $\begin{array}{c}\text { N1-P1 } \\
\text { amplitude }\end{array}$ & $\begin{array}{l}\text { rectified } \\
\text { amplitude }\end{array}$ & N1 & P1 & $\begin{array}{c}\text { N1-P1 } \\
\text { amplitude }\end{array}$ & $\begin{array}{c}\text { rectified } \\
\text { amplitude }\end{array}$ & & \\
\hline \multirow{2}{*}{ F-score } & $r$ & -0.02 & -0.089 & 0.041 & 0.113 & 0.225 & 0.182 & -0.097 & -0.039 & 0.401 & -0.035 \\
\hline & $p$ & 0.934 & 0.709 & 0.864 & 0.635 & 0.34 & 0.442 & 0.686 & 0.869 & 0.08 & 0.885 \\
\hline \multirow{2}{*}{ P-score } & $r$ & -0.375 & -0.043 & -0.297 & -0.011 & -0.324 & -0.291 & -0.198 & -0.203 & 0.035 & -0.283 \\
\hline & $p$ & 0.103 & 0.857 & 0.204 & 0.964 & 0.163 & 0.213 & 0.404 & 0.391 & 0.884 & 0.227 \\
\hline \multirow{2}{*}{ E-score } & $r$ & 0.255 & 0.296 & -0.142 & -0.051 & 0.19 & 0.084 & -0.111 & -0.021 & -0.201 & -0.306 \\
\hline & $p$ & 0.279 & 0.205 & 0.55 & 0.831 & 0.423 & 0.723 & 0.642 & 0.928 & 0.395 & 0.189 \\
\hline \multirow{2}{*}{ total score } & $r$ & -0.065 & 0.043 & -0.143 & 0.031 & 0.046 & 0.003 & -0.158 & -0.103 & 0.131 & -0.229 \\
\hline & $p$ & 0.786 & 0.856 & 0.549 & 0.896 & 0.846 & 0.99 & 0.505 & 0.665 & 0.581 & 0.332 \\
\hline
\end{tabular}

${ }^{*} p$-value is statistically significant; $E=$ emotional; $F=$ functional; $P=$ physical

study, the patients had vertigo as the aura. In comparison, Shalaby et al. [12] found that VEMP abnormality was found in $67 \%$ of those having aura, $62 \%$ of those having vertigo, $100 \%$ of those having dizziness, and $69 \%$ of those having symptoms of brainstem dysfunction. There was no statistically significant difference between the frequency of these symptoms in migraineurs with and without VEMP abnormality.
In contrast to our study, Lipton et al. [23] and Young et al. [24] found that allodynia is very common, affecting roughly $60 \%$ of migraine patients. A potential mechanism for how migraine might be associated with dizziness or vertigo is sensory exaggeration: in migraine, all senses can be more acute, so allodynia is possible. This may make patients with migraine more likely to experience motion sickness and amplify the effects of small amounts of vestibular 
disturbance that other people might not notice [25]. Our results were not in agreement with these researchers, probably because of the smaller percentage of patients having allodynia, even though there were those who had sensory exaggeration to sound and light (phonophobia and photophobia were as high as in previous reports).

Our study agrees with previous studies in that there were comparable cVEMP and oVEMP parameters in migraineurs either with or without vertigo [12,26,27].

Hong et al. [28] assumed that VM patients have difficulty in incorporating somatosensory information. They found an abnormal vestibular ratio in SOT in $45 \%$ of patients with VM, abnormal visual ratio in 58\%, and abnormal SOM ratio in $19 \%$. Jung et al. [20] found that $16 \%, 49 \%$, $58 \%$, and $21 \%$ showed abnormal SOM, VIS, VEST, and VIS PREF ratios, respectively. They thought that an abnormal VEST ratio on posturography and an abnormal VEMP response were frequent findings in VM patients who had had recurrent attacks for more than 6 months and they regarded these indicators as pointing to a poor prognosis. Çelebisoy et al. [29] reported peripheral vestibular dysfunction in VM during the symptom-free period to be more common than a central deficit. However, in the present study the majority of migraineurs had normal equilibrium; after exclusion of peripheral vestibulopathy, vestibular dysfunction was found in $30 \%$. In agreement with the current findings, Çelebisoy et al. [29] also found comparable posturography results between migraineurs with and without vertigo.

In agreement with our study, Mallinson et al. [30] also found that cVEMP and oVEMP abnormalities do not correlate with CDP findings. CDP measures dynamic sway and VEMPs are related to activities involving head movement and are not a measure of body sway [30]. However, Khalil et al. [14] found that there was a significant correlation between abnormal Fukuda, modified clinical test of sensory integration of balance, tandem gait tests, and both cVEMPs and oVEMPs abnormalities.

In the present study, duration of migraine was not correlated to any of the studied VEMP parameters, agreeing with Khalil et al. [14]. Like us, Agrawal et al. [31] also found that amplitude of the oVEMP response decreased significantly with age, suggestive of an age-related decline in utricular function. But Khalil et al. [14] found that there was no significant correlation between age of patients and either cVEMP or oVEMP responses.

Assessed by DHI, the majority of the migraine group, $15 / 20$ patients $(75 \%)$, had a moderate degree of handicap. In contrast to our study, Yip and Strupp [32] did not find any significant correlation between DHI and cVEMP or oVEMP amplitude, or of amplitude asymmetry. They did not find any significant correlation between DHI and postural sway on posturography. They found that patients with central vestibular disorders, excluding migraine, had higher DHI than those with peripheral or functional disorders. However, their study did not include migraine as a central disorder as it has central and peripheral effects. However, the connection between DHI scores and cVEMP amplitude were fairly well correlated.

\section{Conclusions}

cVEMP and oVEMP were present bilaterally in all the migraine patients. In $35 \%$ of patients there was a cVEMP abnormality in the form of delayed latency, reflecting effects of migraine on the vestibulo-spinal reflex. oVEMP was abnormal in $40 \%$ of patients in the form of latency delay, and there was another $10 \%$ with amplitude asymmetry as well, reflecting vestibulo-ocular reflex pathology. On posturography, migraineurs showed a somatosensory defect but only $30 \%$ showed vestibular dysfunction and the majority had a normal equilibrium pattern and normal sensory analyses ratios.

However, cVEMP, oVEMP, and posturography findings did not correlate with clinical symptoms. As age of the migraineurs increased, the oVEMP amplitude decreased. Duration of migraine did not correlate with VEMP parameters.

Our conclusion is that in migraineurs we recommend the use of cVEMP for the assessment of VSR and the use of oVEMP in assessing VOR. We also recommend the use of posturography as complementary testing for full assessment of the VSR in migraine patients.

\section{References}

1. Headache Classification Committee of the International Headache Society (IHS). The International Classification of Headache Disorders, 3rd edition. Cephalalgia, 2018; 38(1): 1-211.

2. Lempert T, von Brevern M. Vestibular Migraine. Neurol Clin, 2019; 37(4): 695-706.

3. Iwasaki S, Smulders Y, Burgess A, McGarvie L, MacDougall H, Halmagyi G. Ocular vestibular evoked myogenic potentials to bone conducted vibration of the midline forehead at Fz in healthy subjects. Clin Neurophysiol, 2008; 119(9): 2135-47.

4. Curthoys IS. A critical review of the neurophysiological evidence underlying clinical vestibular testing using sound, vibration and galvanic stimuli. Clin Neurophysiol 2010; (121): 132-44.

5. Rosengren SM, Welgampola MS, Colebatch JG. Vestibular evoked myogenic potentials: past, present and future. Clin Neurophysiol, 2010; 121: 636-51.
6. Welgampola MS and Colebatch JG. Characteristics and clinical applications of vestibular-evoked myogenic potentials. Neurology, 2005; 24: 1682-8.

7. Todd NPM, Rosengren SM, Aw ST, Colebatch JG. Ocular vestibular evoked myogenic potentials (OVEMPs) produced by air- and bone-conducted sound. Clin Neurophysiol, 2007; 118: 381-90.

8. Pang MY, Lam FM, Wong GH, Au IH, Chow DL. Balance performance in headshake computerized dynamic posturography: aging effects and test-retest reliability. Phys Ther, 2011; 91(2): 246-53.

9. Headache Classification Committee of the International Headache Society (IHS): The International Classification of Headache Disorders, 3rd edition (beta version). Cephalalgia, 2013 Jul; 33(9): 629-808.

10. Alsanosi A. Adaptation of the dizziness handicap inventory for use in the Arab population. Neurosciences, 2012; 17(2): 139-44. 
11. Jacobson G, Newman CW. The development of the Dizziness Handicap Inventory. Arch Otolaryngol Head Neck Surg, 1990; 116: 424-7.凶

12. Shalaby NM, Ramzy GM, Nada MAF, Hussein AF, El-Fayomy NM, El-Minawi MS, Dabbous AO, El-Dessouky T. Assessment of the vestibulo-spinal reflex in migraine patients. Egypt J Neurol Psychiat Neurosurg, 2010; 47(1): 67-74.

13. Kim CH, Jang MU, Choi HC, Sohn JH. Subclinical vestibular dysfunction in migraine patients: a preliminary study of ocular and rectified cervical vestibular evoked myogenic potentials. J Headache Pain, 2015; 16: 93.

14. Khalil LH, Hazzaa NM, Nour AA. Vestibular migraine: a correlation study between clinical findings and vestibular evoked myogenic potentials (VEMPs). Egypt J Ear Nose Throat Allied Sci, 2016; 17: 11-16.

15. Kang WS, Lee SH, Yang CJ, Ahn JH, Chung JW, Park HJ. Vestibular function tests for vestibular migraine: clinical implication of video head impulse and caloric tests. Front Neurol, 2016; 7: 166.

16. Baier B, Stieber N, Dieterich M. Vestibular-evoked myogenic potentials in vestibular migraine. J Neurol, 2009; 256(9): 1447-54

17. Salviza M, Yucec T, Acarb H, Taylana I, Yuceanta GA, Karatasa A. Diagnostic value of vestibular-evoked myogenic potentials in Ménière's disease and vestibular migraine. J Vestib Res, 2015; 25: 261-6.

18. Inoue A, Egami N, Fujimoto C, Kinoshita M, Yamasoba T, Iwasaki S. Vestibular evoked myogenic potentials in vestibular migraine: do they help differentiating from Menière's disease? Ann Otol Rhinol Laryngol, 2016; 125(11): 931-7.

19. Makowiec KF, Piker EG, Jacobson GP, Ramadan NM, Roberts RA. Ocular and cervical vestibular evoked myogenic potentials in patients with vestibular migraine. Otol Neurotol, 2018; 39: 561-7.

20. Zaleski A, Bogle J, Starling A, Zapala DA, Davis L, Wester M, Cevette $M$. Vestibular evoked myogenic potentials in patients with vestibular migraine. Otol Neurotol, 2015; 36: 295-302.

21. Jung JH, Yoo MH, Song CI, Lee JR, Park HJ. Prognostic significance of vestibulospinal abnormalities in patients with vestibular migraine. Otol Neurotol, 2015; 36(2): 282-8.
22. Sürmeli M, Sürmeli R, Deveci I, Önder S, Yalçın AD, Oysu Ç. Correlation between cVEMP and ABR for the evaluation of vestibular migraine. J Int Adv Otol, 2016; 12: 326-31.

23. Lipton, RB, Bigal ME, Ashina S, Burstein R, Silberstein S, Reed ML, Serrano D, Stewart WF. Cutaneous allodynia in the migraine population. Ann Neurol, 2008; 63(2): 148-58.

24. Young WB. Allodynia as a complication of migraine: background and management. Curr Treat Options Neurol, 2009; 11(1): 3-9.

25. Hain T. How Migraine Causes Dizziness. Available at <http:// dizziness-and-balance.com/disorders/central/migraine/how_migraine.html>, accessed June 2020.

26. Roceanu A, Allena M, de Pasqua V et al. Abnormalities of the vestibulo-collic reflex are similar in migraineurs with and without vertigo. Cephalalgia, 2008; 28: 988-90.

27. Özdemir O, Akpınar CK, Küçüköner O, Mehel DM, Bedir A, Akgül G, Can E, Özgür A. Vestibular evoked myogenic potential (VEMP) results in migraine and migrainous vertigo. Acta Otolaryngol, 2020; 140(2): 140-43.

28. Hong HR, Shim DB, Kim TS, Shim BS, Ahn JH, Chung JW, Yoon TH, Park HJ. Results of caloric and sensory organization testing of dynamic posturography in migrainous vertigo: comparison with Meniere's disease and vestibular neuritis. Acta Otolaryngol, 2013; 133: 1236-41.

29. Çelebisoy N, Gökçay F, Şirin H, Biçak N. Migrainous vertigo: clinical, oculographic and posturographic findings. Cephalalgia, 2008; 28: 72-7.

30. Mallinson AI, Kuijpers ACM, Van Zwieten G, Kakal J, Mullings W, Longridge NS. Computerized dynamic posturography does not detect measured CVEMP and OVEMP abnormalities. Gait Posture, 2019; 67: 248-50.

31. Agrawal Y, Zuniga G, Davalos-Bichara M, Schubert MC, Walston JD, Hughes J, Carey JP. Decline in semicircular canal and otolith function with age. Otol Neurotol, 2013; 33(5): 832-9.

32. Yip CW, Strupp M. The Dizziness Handicap Inventory does not correlate with vestibular function tests: a prospective study. J Neurol, 2018; 265(5): 1210-18. 